\title{
Proceso de balcón en cuarentena/ Quarantine balcony in the midst
}

\author{
Sofia Monzon Rodriguez ${ }^{1}$ \\ ${ }^{1}$ Modern Languages and Cultural Studies, University of Alberta, Edmonton, Canada \\ E-mail: monzonro@ualberta.ca
}

Nunca seré ya página en blanco:

los nuevos horizontes se reescriben en medio de mi memoria pero los recuerdos de mi natal legado no consiguen desdibujarse.

El terreno, si bien estos inviernos permanece nevado, siempre llevará ese olor cálido-árido y las líneas, aperpendiculadas, son eternas llanuras en polvo.

En sed y olvido brotarán los pulgares: savia escasa entre escasas aspas.

El lienzo permuta, cambia de pincel de mano.

Los tonos dejan de ser de miel pero son en proceso, siempre en el llegar a ser en la volatilidad de la fragmentación, en el cambio de ciudad

$$
\begin{aligned}
& \text { de lengua } \\
& \text { de continente } \\
& \text { del dador de amor. }
\end{aligned}
$$

Todo se redibuja en mi multiplicidad y el fondo - nunca ya blanco no dejará de ser el flujo de la página inicial.
Never will I ever be

a blank page again:

rewritten in the midst of memory, inherited reminiscences cannot blur themselves.

The soil, still covered in snow, carries a warm-arid scent and the lines, almost perpendicular, eternal dusty plains.

In thirst and oblivion sprouts bloom; scarce sap amidst scarce blades.

The canvas transforms alters the brush alters the hand.

The tones, no longer honey-coloured, but in process in becoming in the volatility of fragmentation in changing cities

$$
\begin{aligned}
& \text { languages } \\
& \text { continents } \\
& \text { the love-giver. }
\end{aligned}
$$

Everything redrawn in this multiplicity and the background - never white ever again to be the flow of the first page. 